Article

\title{
Detection of Borrelia burgdorferi Sensu Lato and Relapsing Fever Borrelia in Feeding Ixodes Ticks and Rodents in Sarawak, Malaysia: New Geographical Records of Borrelia yangtzensis and Borrelia miyamotoi
}

\author{
Alice C. C. Lau ${ }^{1}$, Yongjin Qiu ${ }^{2, *}$, Mohamed Abdallah Mohamed Moustafa ${ }^{3,4}{ }^{(}$, Ryo Nakao ${ }^{3}{ }^{(}$, \\ Michito Shimozuru ${ }^{1}$, Manabu Onuma ${ }^{5}$, Jayasilan Mohd-Azlan ${ }^{6}\left(\mathbb{D}\right.$ and Toshio Tsubota ${ }^{1, *(1)}$ \\ 1 Laboratory of Wildlife Biology and Medicine, Department of Environmental Veterinary Sciences, \\ Faculty of Veterinary Medicine, Hokkaido University, Sapporo 060-0818, Japan; \\ alicelau.cc@vetmed.hokudai.ac.jp (A.C.C.L.); shimozuru@vetmed.hokudai.ac.jp (M.S.) \\ 2 Hokudai Center for Zoonosis Control in Zambia, Research Center for Zoonosis Control, \\ Hokkaido University, Sapporo 001-0020, Japan \\ 3 Laboratory of Parasitology, Department of Disease Control, Faculty of Veterinary Medicine, \\ Hokkaido University, Sapporo 060-0818, Japan; m.abdallah@vetmed.hokudai.ac.jp (M.A.M.M.); \\ ryo.nakao@vetmed.hokudai.ac.jp (R.N.) \\ 4 Department of Animal Medicine, Faculty of Veterinary Medicine, South Valley University, Qena 83523, Egypt \\ 5 Ecological Risk Assessment and Control Section, Center for Environmental Biology and Ecosystem Studies, \\ National Institute for Environmental Studies, Tsukuba 305-806, Japan; monuma@nies.go.jp \\ 6 Institute of Biodiversity and Environmental Conservation, University Malaysia Sarawak, Kota Samarahan, \\ Sarawak 94300, Malaysia; azlan@unimas.my \\ * Correspondence: yongjin_qiu@czc.hokudai.ac.jp (Y.Q.); tsubota@vetmed.hokudai.ac.jp (T.T.); \\ Tel.: +81-11-706-9517 (Y.Q.); +81-11-706-5101 (T.T.)
}

Received: 23 August 2020; Accepted: 14 October 2020; Published: 15 October 2020

\begin{abstract}
Members of the Borrelia burgdorferi sensu lato (Bbsl) complex are etiological agents of Lyme disease (LD), and Borrelia miyamotoi is one of the relapsing fever Borrelia (RFB). Despite the serological evidence of LD in Malaysia, there has been no report from Sarawak, Malaysian Borneo. Thus, this study aimed to detect and characterize Borrelia in rodents and Ixodes ticks from primary forests and an oil palm (OP) plantation in Sarawak. Borrelia yangtzensis (a member of the Bbsl complex) was detected in $43.8 \%$ (14/32) of Ixodes granulatus; most of the positive ticks were from the OP plantation (13/14). Out of 56 rodents, B. yangtzensis was detected in four Rattus spp. from the OP plantation and B. miyamotoi was detected in one rodent, Sundamys muelleri, from the primary forest. Further, the positive samples of $B$. yangtzensis were randomly selected for multilocus sequence analysis (MLSA). The MLSA results of successfully amplified tick samples revealed a clustering with the sequences isolated from Japan and China. This study is the first evidence of $B$. miyamotoi, a known human pathogen in Malaysia, and B. yangtzensis, which is circulating in ticks and rodents in Sarawak, Malaysian Borneo, and presenting a new geographical record of the Borrelia spp.
\end{abstract}

Keywords: Borrelia miyamotoi; Borrelia yangtzensis; Ixodes granulatus; rodent; Sarawak; Malaysia

\section{Introduction}

Members of the Borrelia burgdorferi sensu lato (Bbsl) complex are etiological agents of Lyme disease (LD), and Borrelia miyamotoi is one of the relapsing fever Borrelia (RFB) [1]. There are currently 
more than 20 genospecies in the Bbsl complex reported worldwide [2]. The natural transmission cycles of Bbsl are maintained between their vertebrate reservoir hosts and ixodid (hard) ticks (Acari: Ixodidae) as the vector [3,4]. High incidences of LD and high occurrences of its causative bacterium have been continuously reported since the discovery of LD spirochetes in 1982 in North America and later in 1983 in Europe [4]. In North America, several Bbsl genospecies, including B. burgdorferi sensu stricto (Bbss), B. afzelii, B. garinii, B. californiensis, B. bissettiae, B. kurtenbachii, B. mayonii, and B. spielmanii are known to be responsible for LD [5-9]. While in Europe, Bbss, B. garinii, B. afzelii, and B. bavariensis are the predominant causative bacterium for LD cases [10]. LD remains one of the most important infectious diseases in these two continents. Moreover, this disease is also endemic in east Asian countries as there have been reports from China, Japan, Taiwan, South Korea, and Russia [11,12].

Relapsing fever Borrelia (RFB) is categorized into three genetic groups: New World RFB, Old World RFB, and RFB harbored by ixodid ticks. Among them, New World and Old World RFB are transmitted by soft ticks and louse [13] and are endemic to the African countries, Middle East, Central Asia, southern Europe, and North America [13,14]. On the other hand, RFB harbored by ixodid ticks, including B. miyamotoi, B. lonestari, and B. theileri, are mainly transmitted by the genus Ixodes, Amblyomma, and Rhipicephalus ticks, respectively [15-17]. Among these three, B. miyamotoi is pathogenic to humans [18], and B. theileri is responsible for bovine borreliosis [19]. B. miyamotoi infection in humans was first reported in Russia in 2011, and, since then, cases have been documented in the United States, Europe, Japan, and northeastern China [18,20-23].

Malaysia is geographically located in the Southeast Asian region and is divided into Peninsular Malaysia and Malaysian Borneo. Malaysian Borneo consists of Sarawak and Sabah states and is located in Borneo Island with two other countries: Brunei and Indonesia. Sarawak is the largest state in Malaysia and has tropical geography and equatorial climate. These climatic conditions of relatively high daily average temperature and all-year-round humidity could be ideal for tick survival [24]. Further, Sarawak has undergone massive forest degradation and fragmentation, mainly because of logging activities and oil palm plantations [25,26], and land conversion has been significantly related to increasing emerging or re-emerging zoonotic diseases, including vector-borne diseases [27,28].

To date, the number of studies on tick-borne pathogens, such as Borrelia, has been limited and largely overlooked in Malaysia. Only a few studies on Borrelia spp. were conducted in Peninsular Malaysia, where Borrelia spp., belonging to the RFB group, were detected in the Haemaphysalis hystricis ticks collected from wild boar carcasses [29]. Additionally, Borrelia spp., closely related to B. yangtzensis (a member of Bbsl), were reported from Ixodes granulatus collected from rodents [30]. Moreover, antibodies against LD were detected from both the urban and indigenous people communities; this provided the serological evidence of borrelial infection in humans [31,32]. Nevertheless, no study on Borrelia has been conducted in Malaysian Borneo or Sarawak, so its status is unknown.

Most of the prior studies conducted in Peninsular Malaysia focused on tick surveillance, and little is known about the occurrence of these etiological agents in most parts of Malaysia, including Sarawak. Hence, in this study, we investigated the presence of Borrelia in rodents and Ixodes ticks collected in Sarawak, Malaysian Borneo.

\section{Results}

\subsection{Identification of Rodent and Tick Species}

Overall, we trapped 97 rodents from two primary forests, Gunung Gading National Park (GGNP) and Kubah National Park (KNP), and an oil palm (OP) plantation, out of which 56 rodents were selected and used for this study based on the research permissions (Figure 1). Sample identity was sampling site abbreviation (KNP-, GGNP-, and OP-), followed by a numerical assignment. The morphological and molecular identification of the rodents revealed 4 Leopodamys sabanus, 2 Maxomys rajah, 2 M. whiteheadi, 45 Rattus spp. and 3 Sundamys muelleri (Table 1). The rodents that were morphologically assigned to 
the Rattus spp., R. tiomanicus, and R. tanezumi, were collectively grouped as one Rattus spp., as they were not molecularly identified as a single species.

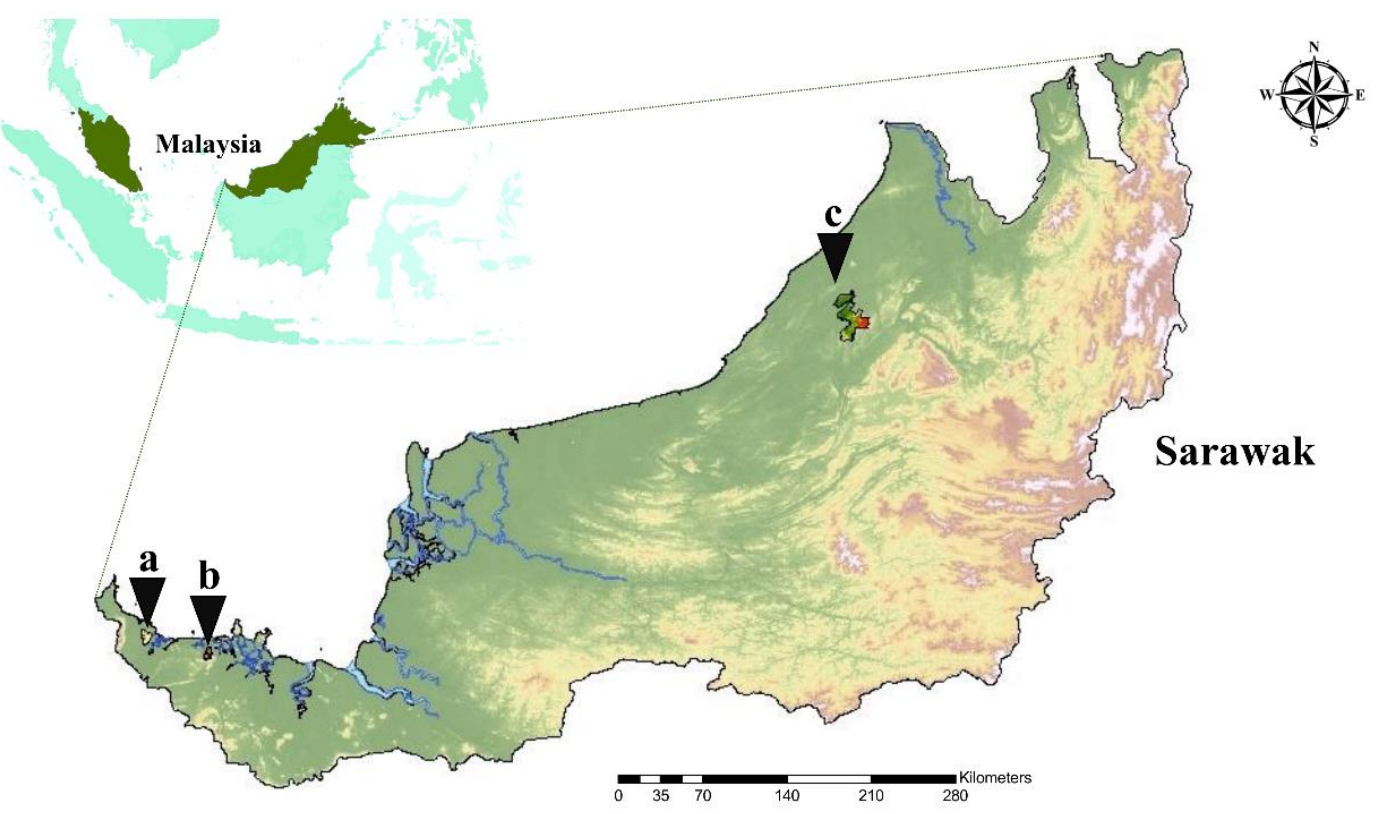

Figure 1. Map of the sampling sites. (a) Gunung Gading National Park, (b) Kubah National Park, and (c) oil palm plantation.

Table 1. The number of rodent species and Ixodes granulatus used for the screening of Borrelia spp.

\begin{tabular}{ccccc}
\hline & \multicolumn{3}{c}{ Sampling Period } & \\
\cline { 2 - 4 } & \multicolumn{1}{c}{ November 2018 } & March 2019 & \\
\hline Rodent Species & GGNP & KNP & OP Plantation & Total \\
\hline Leopodamys sabanus & $0 / 2$ & $0 / 2$ & N/A & $0 / 4$ \\
Maxomys rajah & N/A & $0 / 2$ & N/A & $0 / 2$ \\
Maxomys whiteheadi & $0 / 2$ & N/A & N/A & $0 / 2$ \\
Rattus spp. & N/A & $0 / 3$ & $4 / 42$ & $4 / 45$ \\
Sundamys muelleri & $1 / 2$ & N/A & $0 / 1$ & $1 / 3$ \\
\hline Total & $1 / 6$ & $0 / 7$ & $4 / 43$ & $5 / 56$ \\
\hline Ixodes granulatus & GGNP & KNP & OP Plantation & Total \\
\hline Female & $0 / 3$ & $1 / 9$ & $10 / 10$ & $11 / 22$ \\
Nymph & N/A & $0 / 2$ & $1 / 3$ & $1 / 5$ \\
Larva & N/A & N/A & $2 / 5$ & $2 / 5$ \\
\hline Total & $0 / 3$ & $1 / 11$ & $13 / 18$ & $14 / 32$
\end{tabular}

No. of positive/No. of tested. Gunung Gading National Park (GGNP), Kubah National Park (KNP), oil palm (OP).

A total of 32 Ixodes ticks (22 females, 5 nymphs, and 5 larvae) were collected from the rodents and molecularly identified as I. granulatus (Table 1). All the I. granulatus ticks were engorged or semi-engorged, except for one larva from the OP plantation. A similar system was also applied for tick sample identity, by using IG as the acronym for I. granulatus.

\subsection{Detection of the Borrelia spp.}

Out of the 56 rodent samples, four Rattus spp. (Sample IDs: OP-007, -014, -018, and -033) from the OP plantation and one S. muelleri (Sample ID: GGNP-04) from the GGNP were positive for the borrelial flagellin gene $(f l a B)$ in a polymerase chain reaction (PCR) (Table 1). The prevalence of Borrelia spp. in 
rodents from GGNP, KNP, and the OP plantation were $16.7 \%(1 / 6), 0 \%(0 / 7)$, and 8.9\% (4/45), respectively (Table 1). Subsequent analysis revealed that sequences from these five samples were different from each other. The sequences from OP-007 and OP-014 showed 100\% (300/300 bp) and 95\% (285/300 bp) identity, respectively, with $B$. yangtzensis in $I$. granulatus extracted from rodent Niviventer fulvescens in China (EU135602). The sequence from OP-018 showed 100\% (300/300 bp) identity with B. valasiana-related genospecies from rodent Suncus murinus in Japan (AB091710). The sequence from OP-033 showed 99.3\% (298/300 bp) identity with B. valasiana-related genospecies from rodent Apodemus agrarius in China (AB022136). Finally, the sequence from GGNP-04 showed 100\% (294/294 bp) identity with B. miyamotoi from I. nipponensis in South Korea (MH102393). For further characterization of the Borrelia spp., subsequent nested PCRs targeting the borrelial 16S ribosomal DNA (rDNA) were carried out and successful in four of the samples (OP-014, -018, -033, and GGNP-04). The sequence from OP-014 showed $99.6 \%$ (1348/1354 bp) identity with B. yangtzensis from H. longicornis in China (EU135595). The sequence from OP-018 showed $99.7 \%$ (1350/1354 bp) identity with $B$. valasiana-related genospecies from rodent $A$. agrarius in China (AB022141). The sequence from OP-033 showed 99.9\% identity with B. valasiana-related genospecies from South Korea (U44938). Finally, the sequence from GGNP-04 showed $99.8 \%$ (1352/1355 bp) identity with B. miyamotoi from a febrile patient in Russia (CP037471).

Out of 32 I. granulatus samples, 14 samples (43.8\%) were positive for flaB-PCR. The 14 samples included 1 female from KNP and 10 females, 1 nymph, and 2 larvae from the OP plantation (Table 1). None of the I. granulatus samples from GGNP were positive for flaB-PCR. In addition, only one positive I. granulatus sample (Sample ID: IG-218) was harvested from the Bbsl positive rodent, OP-033. Among the three sampling sites, the OP plantation recorded the highest number of tested samples and the highest prevalence of positive samples $(72.2 \% ; 13 / 18$; Table 1$)$. The details for the sequencing results of both flaB and $16 \mathrm{~S}$ rDNA were shown in Table 2. From the sequence analysis, six I. granulatus (Sample IDs: IG-204, -206, -208, -213, -217, and -218) had an identical sequence of flaB, i.e., $100 \%$ (300/300 bp) identity with B. yangtzensis (EU135602). This sequence was also identical to that from the rodent sample, OP-007. Additionally, sequences from sample IDs: IG-214, -216, -220, -221, -222, and -228) were identical with Bbsl sequences from I. granulatus in Taiwan (HM853004), China (MG717513 and MG717514), and Malaysia (LT969779) (Table 2). Finally, the sequences from sample IDs: IG-215 and -219 showed 99.3\% (298/300 bp) and 100\% (300/300 bp) identity, respectively, with B. valaisiana-related genospecies (AB091710), and the sequence from IG-215 was identical to that from the rodent sample, OP-018. Additionally, 7 out of the 14 I. granulatus samples with a positive flaB-PCR were successfully sequenced for $16 \mathrm{~S}$ rDNA. The sequences showed high similarity with B. yangtzensis from China (EU135595 and EU135598) and South Korea (L39080) and with B. valaisiana-related genospecies from China (AB022140 and AB022141) (Table 2). Similarly, the same sequences were also detected in both tick and rodent samples. The sequence from IG-219 had an identical sequence to the rodent sample, OP-018.

Table 2. The sequence analysis results for the borrelial flagellin gene (flab) and $16 \mathrm{~S}$ ribosomal DNA (rDNA) of Ixodes ticks.

\begin{tabular}{|c|c|c|c|c|}
\hline Gene & Sample ID & BLASTn & Identity & Accession No. \\
\hline \multirow[t]{12}{*}{ flaB } & IG-204 & Borrelia yangtzensis strain QTMP2 (China) & $100 \%(300 / 300 \mathrm{bp})$ & EU135602 \\
\hline & IG-206 & Borrelia yangtzensis strain QTMP2 (China) & $100 \%(300 / 300 \mathrm{bp})$ & EU135602 \\
\hline & IG-208 & Borrelia yangtzensis strain QTMP2 (China) & $100 \%(300 / 300 \mathrm{bp})$ & EU135602 \\
\hline & IG-217 & Borrelia yangtzensis strain QTMP2 (China) & $100 \%(300 / 300 \mathrm{bp})$ & EU135602 \\
\hline & IG-218 & Borrelia yangtzensis strain QTMP2 (China) & $100 \%(300 / 300 \mathrm{bp})$ & EU135602 \\
\hline & IG-215 & Borrelia valaisiana-related genospecies (Japan) & $99.3 \%(298 / 300 \mathrm{bp})$ & AB091710 \\
\hline & IG-214 & Borrelia sp. TKM-30 from Ixodes granulatus (Taiwan) & $99.3 \%(298 / 300 \mathrm{bp})$ & HM853004 \\
\hline & IG-216 & Borrelia sp. TKM-30 from Ixodes granulatus (Taiwan) & $99.3 \%(298 / 300 \mathrm{bp})$ & HM853004 \\
\hline & IG-220 & Uncultured Borrelia sp. clone Borr65 from Ixodes granulatus (China) & $100 \%(300 / 300 \mathrm{bp})$ & MG717514 \\
\hline & IG-221 & Uncultured Borrelia sp. clone BorrIg from Ixodes granulatus (China) & $99.0 \%(297 / 300 \mathrm{bp})$ & MG717513 \\
\hline & IG-222 & Uncultured Borrelia sp. from Ixodes granulatus (Malaysia) & $99.7 \%(299 / 300 \mathrm{bp})$ & LT969779 \\
\hline & IG-228 & Uncultured Borrelia sp. from Ixodes granulatus (Malaysia) & $100 \%(300 / 300 \mathrm{bp})$ & LT969779 \\
\hline
\end{tabular}


Table 2. Cont.

\begin{tabular}{|c|c|c|c|c|}
\hline Gene & Sample ID & BLASTn & Identity & Accession No. \\
\hline \multirow[t]{6}{*}{ 16S rDNA } & IG-213 & Borrelia yangtzensis strain QX-S13 (China) & $99.5 \%(1347 / 1354 \mathrm{bp})$ & EU135598 \\
\hline & IG-216 & Borrelia sp. 9MT (South Korea) & $99.8 \%(1351 / 1354 \mathrm{bp})$ & L39080 \\
\hline & IG-217 & $\begin{array}{l}\text { Borrelia valaisiana-related genospecies from rodent } \\
\qquad \text { Apodemus agrarius (China) }\end{array}$ & $99.6 \%(1348 / 1354 \mathrm{bp})$ & АB022140 \\
\hline & IG-220 & $\begin{array}{l}\text { Borrelia valaisiana-related genospecies from rodent } \\
\qquad \text { Apodemus agrarius (China) }\end{array}$ & $99.6 \%(1346 / 1352 \mathrm{bp})$ & AB022140 \\
\hline & IG-218 & Borrelia yangtzensis strain QSYSP3 (China) & $99.8 \%(1351 / 1354 \mathrm{bp})$ & EU135595 \\
\hline & IG-221 & $\begin{array}{l}\text { Borrelia valaisiana-related genospecies from rodent } \\
\text { Apodemus agrarius (China) }\end{array}$ & $99.6 \%(1349 / 1354 \mathrm{bp})$ & AB022141 \\
\hline
\end{tabular}

\subsection{Phylogenetic Analysis}

Collectively, 19 samples (5 rodents and 14 I. granulatus) were positive for flaB-PCR and were included in the phylogenetic tree construction. Out of 19 samples, 18 were assigned to the clade of Bbsl and clustered together with B. yangtzensis or B. valaisiana-related genospecies (Figure 2). The remaining rodent sample (GGNP-04) was assigned to the RFB and clustered together with B. miyamotoi (Figure 2). In addition, the phylogenetic tree based on the $16 \mathrm{~S}$ rDNA sequences revealed the consistent clustering, as observed in flaB (Figure 3).

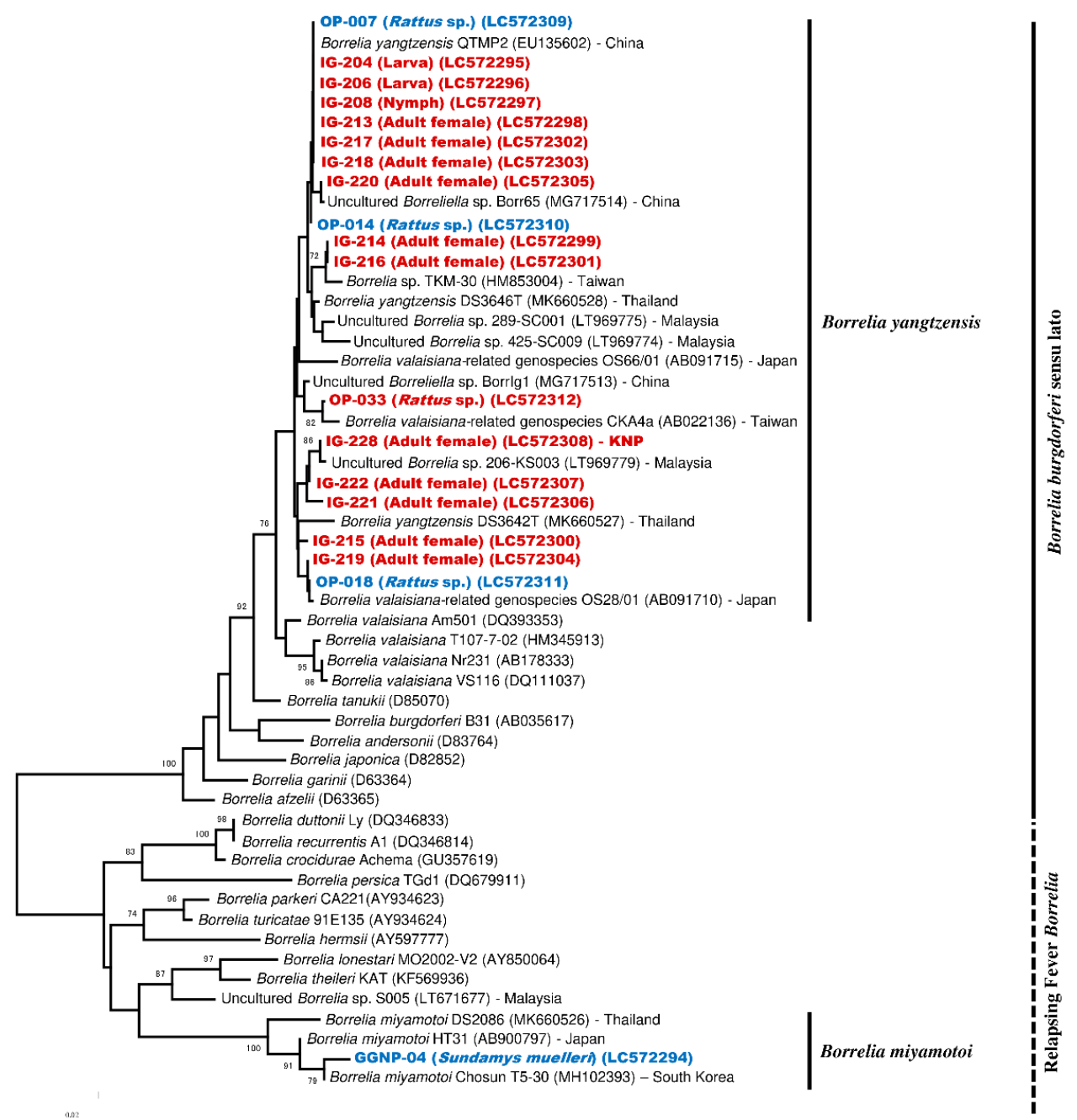

Figure 2. Phylogenetic tree based on flaB sequences of the Borrelia species. The phylogenetic tree was constructed in MEGA version $X$ by the Neighbor-Joining model with Kimura-2 parameter and 
1000 bootstrap replications. The sequences from ticks and rodents obtained in this study are shown in red and blue, respectively. All positive tick samples were collected from an oil palm (OP) plantation; the location is not indicated except for one sample from Kubah National Park (KNP). The individual rodent IDs are shown with the sampling sites: Gunung Gading National Park (GGNP) or the OP plantation.

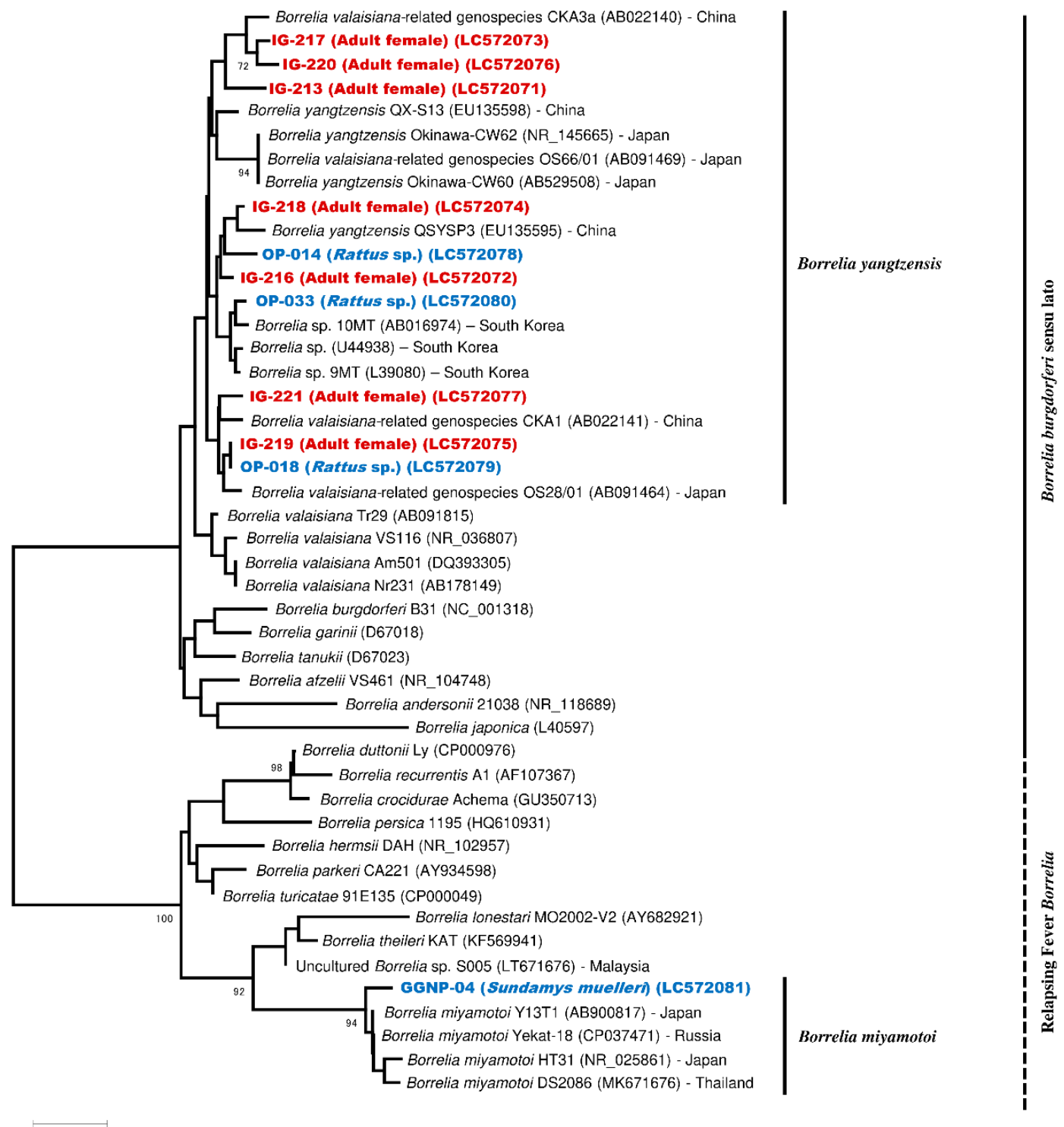

Figure 3. Phylogenetic tree based on $16 \mathrm{~S}$ rDNA sequences of the Borrelia species. The phylogenetic was constructed in MEGA version X by the Neighbor-Joining model with Kimura-2parameter and 1000 bootstrap replications. The sequences from ticks and rodents obtained in the present study are shown in red and blue, respectively. All samples were collected from an oil palm (OP) plantation, except one sample, which was from Gunung Gading National Park (GGNP).

\subsection{Multilocus Sequence Analysis of the Borrelia spp.}

All I. granulatus samples included for the multilocus sequence analysis (MLSA) were successfully amplified for the eight housekeeping genes. In the phylogenetic tree based on the concatenated MLSA genes, the Borrelia spp. from I. granulatus were located in the clade of B. yangtzensis (Figure 4). This trend was also confirmed in the other phylogenetic trees based on flaB and 16S rDNA (Figures 2 and 3). For the four rodent samples included in MLSA, a minimum of two (1/4), four (2/4), and six (1/4) 
housekeeping genes were successfully amplified. Therefore, the phylogenetic inferences of the Borrelia species in both rodent and tick samples were done on a per-gene basis. The phylogenetic analysis based upon each housekeeping gene showed that the rodent samples (OP-007, -014, -018, and -033) were located in the clade of B. yangtzensis with I. granulatus from this study (Figure S1).

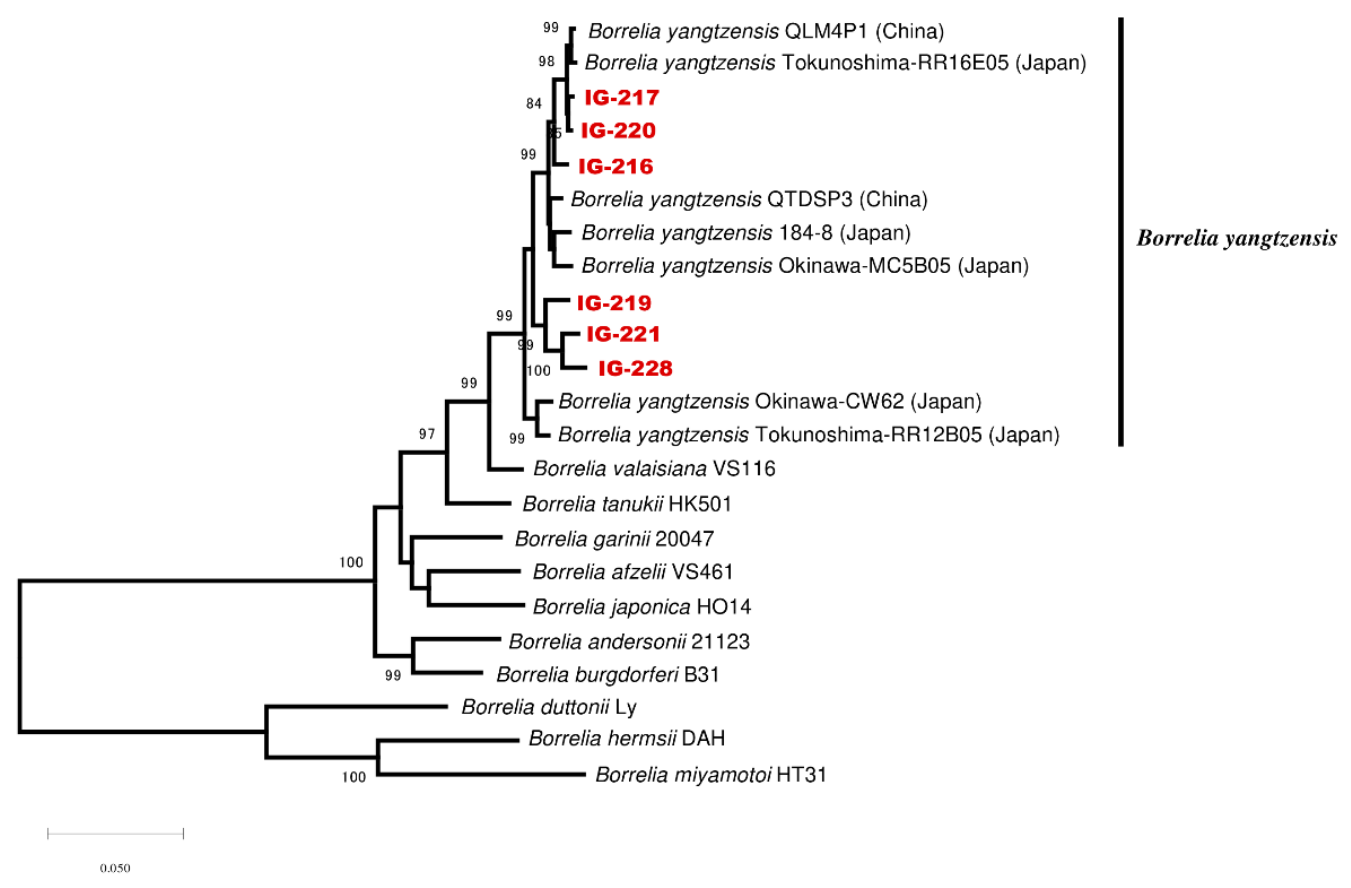

Figure 4. Phylogenetic inference of the Borrelia burgdorferi sensu lato. The samples are shown in red. The sequences obtained from eight housekeeping genes were trimmed and concatenated in the order of $\operatorname{clpA}, \operatorname{clpX}$, nifS, pepX, pyrG, recG, rplB, and $u v r A$, according to the Borrelia PubMLST database. The maximum likelihood model was used with 1000 bootstrap replications for the phylogenetic construction in MEGA version $\mathrm{X}$.

\section{Discussion}

We investigated Borrelia spp. in I. granulatus and rodents, L. sabanus, M. rajah, M. whiteheadi, Rattus spp. and S. muelleri from primary forests (GGNP and KNP) and an OP plantation in Sarawak, Malaysia. We identified B. yangtzensis from I. granulatus and Rattus spp. and B. miyamotoi from S. muelleri. This study is the first evidence of B. miyamotoi in Malaysia and B. yangtzensis in Sarawak, Malaysian Borneo.

Borrelia yangtzensis detected from I. granulatus in this study was formerly known as B. valaisiana-related genospecies since phylogenetic inferences showed a close relation but a clear distinction to B. valaisiana (a member of the Bbsl complex in Europe) [33]. However, unlike B. valaisiana that utilize birds as the reservoir host and Ixodes ticks as the vector [33,34], B. yangtzensis is maintained and transmitted through a natural infection cycle between rodents and Ixodes ticks [35]. Isolations of B. yangtzensis from different rodent species were recorded from Rattus spp., S. murinus, Mus spp. and A. agrarius in Japan, China, and Taiwan [35-37], as well as from different Ixodes tick species, such as I. nipponensis in South Korea and I. granulatus in Japan and China [35,38,39]. Recently, a Borrelia sp. closely related to B. yangtzensis was detected in Peninsular Malaysia from I. granulatus collected from different rodent species [30]. Takhampunya et al. [40] also identified B. yangtzensis from one rodent and two tick pools of Ixodes spp. collected from rodents in northern Thailand. This is similar to our study, as we detected B. yangtzensis from Rattus spp. and I. granulatus for the first time in Sarawak. These results suggest that B. yangtzensis is circulated and Rattus spp. and I. granulatus play the roles of the natural reservoir and vector, respectively, in Sarawak. However, there is a limitation in our study; 
as all of the positive Ixodes ticks were engorged, we could not rule out whether borrelial DNA detected from the tick samples was from the blood meal host or not. Thus, further investigations of B. yangtzensis in unfed $I$. granulatus are required to confirm the vector species of this bacterium in Sarawak. In addition, I. granulatus has been documented from migratory birds in Taiwan by Kuo et al. [41]. Migratory birds are known to play an important role in the dispersal of Bbsl, with previous reports involving Ixodes ticks from Japan, South Korea, and Russia [42-44]. Moreover, studies in Canada by Scott et al. showed that migratory birds disperse Bbsl-infected ticks over a long distance and across geographical barriers $[45,46]$. Thus, investigation of ticks collected from migratory birds in Malaysia might help expand our knowledge of Bbsl, including B. yangtzensis.

Multilocus sequence analysis was first introduced by Margos et al. [47] for depicting the evolutionary processes of B. burgdorferi. By targeting multi loci, eight housekeeping genes were developed for the Bbsl complex [47] and have been subsequently used in other studies to characterize the complexity of the Bbsl genospecies [33,35]. In recent years, this method has also proven to be useful in comparing the intraspecific diversity, elucidating population genetic structure, and other ecological aspects that may contribute to the transmission dynamics of the Bbsl genospecies [48,49]. Further, MLSA has been used to confirm B. yangtzensis from the isolates of ticks and rodents from China and Japan [33]. Based on MLSA, the phylogeny inference revealed that the isolates formed two sister clusters, with each cluster consisting of isolates from both China and Japan. Concordantly, in our study, the concatenated sequences of $B$. yangtzensis from I. granulatus were also located in two sister clades.

On the human pathogenic aspect, B. valaisiana had been regarded as the causative agent of LD in humans but was recently proven otherwise [50]. Two human LD cases caused by B. valaisiana-related genospecies were reported from Japan and China [51,52], but Margos et al. [33,50] later on ratified them be B. yangtzensis and suggested B. valaisiana as a non-human pathogenic. Although B. yangtzensis may potentially be a human pathogenic, there is currently no study providing further evidence. Even though the significance of B. yangtzensis in humans and animals is not yet fully understood, the findings of B. yangtzensis in our study imply the likelihood that the bacterium circulates within the Ixodes ticks and rodents in primary forests and OP plantation in Sarawak. Borrelia spp. closely related to B. yangtzensis were also detected from I. granulatus in Peninsular Malaysia [26]. Of note, I. granulatus is a rare parasite of humans with few related reports. Yun et al. [53] identified only one female of I. granulatus from 261 ticks they collected from humans in South Korea. A checklist of ticks from Thailand, dated back to 1983, documented that humans could be hosts for this tick species [54]. However, it was not clear in these studies whether the I. granulatus collected were biting humans. Thus, more investigations are required to evaluate the pathogenicity to humans and understand the transmission cycle of B. yangtzensis in Malaysia.

Borrelia miyamotoi, the causative agent of RF, was first isolated from I. persulcatus ticks in Japan. To date, several Ixodes tick species are considered as a vector of B. miyamotoi. For instance, I. scapularis and I. pacificus are the vectors reported in the United States and Canada, I. ricinus in Europe, and I. persulcatus in Europe and Asia [16,23,55-57]. So far, the reservoir hosts, based on the geographical distribution, for B. miyamotoi are still not well understood, but rodents and birds have been considered as the reservoir hosts in some regions [58,59]. In this study, we detected B. miyamotoi from $S$. muelleri in GGNP; this is the first report of B. miyamotoi in Malaysia. However, none of the I. granulatus examined in this study were positive for B. miyamotoi. Furthermore, the infection rate of B. miyamotoi was lower than that of B. yangtzensis in this study. Generally, the infection rate of B. miyamotoi in rodents and ticks appears to be lower than that of Bbsl species as per previous studies in Japan and Russia [56,58]. Further, another study on the prevalence of B. miyamotoi infection in $I$. scapularis conducted in Canada was low $(<1 \%)$ [57]. Moreover, the reported prevalence of B. miyamotoi in questing Ixodes ticks ranged from $1.3 \%$ in I. Ricinus to $3.6 \%$ in I. persulcatus [60]. For future studies, the sample size of the rodents and ticks should be increased to find the vector tick species and to describe the diversity and distribution of B. miyamotoi in Sarawak. In addition, B. miyamotoi has been recently reported from 
H. concinna in Northeastern China [23]. In Europe, migratory birds have been reported as the reservoir host of B. miyamotoi or play a role in the dispersal of tick vectors [59]. Thus, the investigations of other tick species and birds may provide more in-depth insights of B. miyamotoi in Sarawak.

The sampling in this study was conducted only once for the primary forests (GGNP and KNP) and the OP plantation in different seasons, which yielded a small sample size, especially in the sampling during the wet season. A small sample size and lack of sampling repetition may have contributed to the low number of positive samples in this study; as B. miyamotoi was only positive in one rodent, and B. yangtzensis was not detected in the rodents from GGNP and KNP. In addition, only rodent spleens were used in this study for Bbsl and RFB screening. Future work to estimate the prevalence should include ear biopsies and other internal organs, as Bbsl and B. miyamotoi may not have the same strategies for maintenance and dissemination in the same reservoir host [61]; therefore, different tissue may yield different detection rate [62]. Despite the incomparable rodent numbers, the number of Ixodes ticks from the primary forests and OP plantation were fairly similar (14 and 18, respectively). In the OP plantation, 13 ticks were positive for B. yangtzensis; in contrast, in the primary forests, only one tick from KNP was positive. Land conversion with a human-dominated ecosystem could have a potent effect on reservoirs and the zoonotic risk, because of the alterations of host diversity and composition $[63,64]$. The difference observed in this study might be reflected by the variation between the primary forest and OP plantation. A follow-up study to evaluate this hypothesis should encompass a larger sampling size with repetition.

In conclusion, we examined Borrelia spp. in rodents and ticks from primary forests and an OP plantation. We reported the presence of B. miyamotoi for the first time in Malaysia. We also reported the first detection of $B$. yangtzensis, which was characterized using MLSA, in both rodents and I. granulatus in Sarawak. These findings of Borrelia spp. in Sarawak provide evidence of a new geographical record. Our study warrants the need for further investigations as it is important to determine how the Borrelia spp. may impact public health in Malaysia.

\section{Materials and Methods}

\subsection{Ethics Approvals}

The collecting of rodents and ticks was approved by the Sarawak Forests Department, Malaysia (Permit No. (91) JHS/NCCD/600-7/2/107 and Park Permit No. WL47/2018; Permit No. (11) JHS/NCCD/6007/2/107(Jld2) and Park Permit No.WL5/2019). The sampling methods were approved by the Animal Care and Use Committee of Hokkaido University, Japan (Approval No. 18-0081). The samples were exported with the permission of the Sarawak Forests Department (No.18650).

\subsection{Survey Sites and Sample Collection}

We selected the protected primary forests, GGNP $\left(1.69^{\circ} \mathrm{N}, 109.85^{\circ} \mathrm{E}\right)$ and $\mathrm{KNP}\left(1.61^{\circ} \mathrm{N}, 110.20^{\circ}\right.$ E), and an OP plantation $\left(3.36^{\circ} \mathrm{N}, 113.69^{\circ} \mathrm{E}\right)$ in Sarawak as the study sites. The rodents and ticks attached to the rodent hosts were collected from GGNP and KNP during the wet season in November 2018 and from the OP plantation during the dry season in March 2019 (Figure 1; Table 1). The sampling period for each site ranged from 5-10 days. The rodents were captured using collapsible cage traps; their tentative species, sex, breeding status, and body measurements were recorded. The captured rodents were individually anesthetized using isoflurane. Next, the ticks attached to each rodent were collected and kept separately in $70 \%$ ethanol. In addition, the selected rodents were euthanized following the method described by Taylor et al. [58] for internal organs collection. Finally, the harvested organs were kept in $70 \%$ ethanol and subsequently stored at $-20{ }^{\circ} \mathrm{C}$ after being transferred back to the facility; the spleen samples of the rodents were used in this study. 


\subsection{DNA Preparation and Species Identification of Rodents and Ticks}

DNA was extracted from the rodent spleens at the Faculty of Resource Science and Technology, Universiti Malaysia Sarawak, using a Wizard ${ }^{\circledR}$ Genomic DNA Purification Kit (Promega, Madison, WI, USA), following the manufacturer's instructions. The DNA samples and ticks were sent to Hokkaido University, Japan, where the subsequent screenings and analyses of the samples were conducted.

For the molecular identification of the rodent species, we amplified a fragment of the cytochrome c oxidase subunit 1 (CO1) by polymerase chain reaction (PCR) using the primer pairs BatL5310 and R6036R (Table 3) [65]. The PCRs were conducted in a $20 \mu \mathrm{L}$ reaction mixture using the Ex Taq Hot Start version (Takara Bio, Shiga, Japan) with the following conditions: 30 cycles of denaturation at $94{ }^{\circ} \mathrm{C}$ for $30 \mathrm{~s}$, annealing at $48^{\circ} \mathrm{C}$ for $30 \mathrm{~s}$, and extension at $72{ }^{\circ} \mathrm{C}$ for $60 \mathrm{~s}$.

The tick genera or species were morphologically identified based on the taxonomic keys $[66,67]$, and a fragment of their mitochondrial 16S ribosomal DNA (16S rDNA; Table 3) was confirmed by sequencing [68]. One leg of the ticks was removed, and DNA was extracted from it by using the hot alkaline extraction method previously described by Mtambo et al. [69], with some modifications. Briefly, we added $10 \mu \mathrm{L}$ of $100 \mathrm{nM}$ of sodium hydroxide and incubated it at $95^{\circ} \mathrm{C}$ for $10 \mathrm{~min}$, followed by adding $2 \mu \mathrm{L}$ of tris-hydrochloride buffer ( $\mathrm{pH}$ 7.0). The PCR was conducted using Tks Gflex DNA Polymerase (Takara Bio, Shiga, Japan), with the following conditions: initial denaturation at $94{ }^{\circ} \mathrm{C}$ for $1 \mathrm{~min}$, followed by 40 cycles of $98^{\circ} \mathrm{C}$ for $10 \mathrm{~s}, 55^{\circ} \mathrm{C}$ for $15 \mathrm{~s}$, and $68^{\circ} \mathrm{C}$ for $24 \mathrm{~s}$, and a final extension at $68^{\circ} \mathrm{C}$ for $5 \mathrm{~min}$.

The amplification products from rodents and ticks were electrophoresed on a $1.2 \%$ agarose gel with Midori Green Direct DNA stain (Nippon Genetics, Tokyo, Japan) and visualized with a BLooK LED transilluminator (GeneDireX, Las Vegas, NV, USA). The Sanger sequencing was performed using the BigDye Terminator version 3.1 Cycle Sequencing Kit (Applied Biosystems, Foster City, CA, USA). The sequencing products were analyzed on an ABI Prism $3130 \mathrm{x}$ genetic analyzer (Applied Biosystems, Foster City, CA, USA), according to the manufacturer's instructions. The sequences were compared with public databases using the Nucleotide Basic Local Alignment Search Tool (BLASTn) (https://blast.ncbi.nlm.nih.gov/Blast.cgi). In addition, the Barcode of Life Data System (BOLD; http://www.barcodinglife.org) was also used for rodent identification [70].

After identifying the tick species, the remaining body of the Ixodes ticks was washed with sterile phosphate-buffered saline and individually crushed with Micro Smash MS-100R (TOMY, Tokyo, Japan) for $30 \mathrm{~s}$ at $2500 \mathrm{rpm}$. The DNA was extracted using the Wizard ${ }^{\circledR}$ Genomic DNA Purification Kit (Promega, Madison, WI, USA), as described above. 
Table 3. The primers used in this study.

\begin{tabular}{|c|c|c|c|c|c|}
\hline Primer Name & Sequence $\left(5^{\prime}\right.$ to $\left.3^{\prime}\right)$ & Target Gene (PCR Type) & $\begin{array}{l}\text { Annealing } \\
\text { Temperature }\left({ }^{\circ} \mathrm{C}\right)\end{array}$ & Amplicon Size (bp) & Reference \\
\hline $\begin{array}{l}\text { mt-rrs1 } \\
\text { mt-rrs2 }\end{array}$ & $\begin{array}{l}\text { CTGCTCAATGATTTTTTAAATTGCTGTGG } \\
\text { CCGGTCTGAACTCAGATCAAGTA }\end{array}$ & $\begin{array}{l}\text { Mitochondrial } 16 \mathrm{~S} \text { rDNA of tick } \\
\text { (Single PCR) }\end{array}$ & 55 & $\sim 400$ & {$[68]$} \\
\hline $\begin{array}{l}\text { BatL5310 } \\
\text { R6036R }\end{array}$ & $\begin{array}{l}\text { CCTACTCRGCCATTTTACCTATG } \\
\text { ACTTCTGGGTGTCCAAAGAATCA }\end{array}$ & CO1 of rodents (Single PCR) & 48 & 750 & {$[70]$} \\
\hline $\begin{array}{l}\text { BflaPAD } \\
\text { BflaPDU }\end{array}$ & $\begin{array}{l}\text { GATCARGCWCAAYATAACCAWATGCA } \\
\text { AGATTCAAGTCTGTTTTGGAAAGC }\end{array}$ & flaB of Borrelia (1st PCR) & 55 & 800 & {$[71]$} \\
\hline $\begin{array}{l}\text { BflaPBU } \\
\text { BflaPCR }\end{array}$ & $\begin{array}{l}\text { GCTGAAGAGCTTGGAATGCAACC } \\
\text { TGATCAGTTATCATTCTAATAGCA }\end{array}$ & flaB of Borrelia (2nd PCR) & 50 & 345 & {$[71]$} \\
\hline $\begin{array}{l}\mathrm{fD} 1 \\
\mathrm{rp} 2\end{array}$ & $\begin{array}{l}\text { AGAGTTTGATCCTGGCTCAG } \\
\text { ACGGCTACCTTGTTACGACTT }\end{array}$ & $\begin{array}{l}\text { Universal primer for } 16 \mathrm{~S} \text { rDNA of } \\
\text { bacteria (1st PCR for rodent samples) }\end{array}$ & 55 & 1400 & {$[72]$} \\
\hline $\begin{array}{l}\text { BF1 } \\
\text { BR1 }\end{array}$ & $\begin{array}{l}\text { GCTGGCAGTGCGTCTTAAGC } \\
\text { GCTTCGGGTATCCTCAACTC }\end{array}$ & $\begin{array}{l}\text { 16S rDNA of Borrelia (Single PCR for } \\
\text { tick and 2nd PCR for rodent samples) }\end{array}$ & 55 & 1371 & [73] \\
\hline $\begin{array}{l}{ }^{*} \text { BF3_seq } \\
{ }^{*} \text { BR3_seq }\end{array}$ & $\begin{array}{l}\text { AGATACCCTGGTAGTCTACGCT } \\
\text { GCTGCTGGCACGTAATTAGC }\end{array}$ & $16 \mathrm{~S}$ rDNA of Borrelia & N/A & N/A & This study \\
\hline
\end{tabular}

* Primers were used in sequencing. 


\subsection{Screening of the Borrelia spp.}

DNA from the rodent spleens and Ixodes ticks were subjected to the screening of Bbsl and RFB using a nested PCR targeting the flaB, which is a $345 \mathrm{bp}$ amplicon (Table 3) [71]. The PCR conditions were as follows: 25 and 30 cycles of denaturation at $94{ }^{\circ} \mathrm{C}$ for $30 \mathrm{~s}, 55^{\circ} \mathrm{C}$ and $50{ }^{\circ} \mathrm{C}$ of annealing for $30 \mathrm{sec}$, and extension at $72{ }^{\circ} \mathrm{C}$ for $1 \mathrm{~min}$ in the first and second PCR, respectively. The positive samples of the flaB-PCR were further characterized by additional PCRs, targeting $16 \mathrm{~S}$ rDNA, which is approximately a $1370 \mathrm{bp}$ amplicon. For the Ixodes ticks, a single PCR with BF1 and BR1 primers was performed [73] (Table 3). While, for the rodent samples, universal primers targeting bacterial 16S rDNA were added for the first PCR [72], BF1 and BR1 primers were added for the second PCR. The PCR conditions for the single and nested PCRs were identical, i.e., 35 cycles of denaturation at $94{ }^{\circ} \mathrm{C}$ for $30 \mathrm{~s}$, annealing at $55{ }^{\circ} \mathrm{C}$ for $30 \mathrm{~s}$, followed by extension at $72{ }^{\circ} \mathrm{C}$ for $90 \mathrm{~s}$. The PCR was conducted using the Ex Taq Hot Start version (Takara Bio, Shiga, Japan) with a reaction mixture of $20 \mu \mathrm{L}$. DNA from "Candidatus Borrelia fainii" strain Qtaro [74] and molecular-grade water were used for the positive and negative controls, respectively. Finally, the electrophoresis, PCR product purification, and Sanger sequencing were performed as mentioned in the subsection "DNA preparation and species identification of rodents and ticks".

\subsection{Multilocus Sequence Analysis of the Borrelia spp.}

Four rodent and six tick samples were randomly selected from the flaB and 16S rDNA PCR positive samples and were used for MLSA based on the sequences of eight housekeeping genes $(\operatorname{clp} A, \operatorname{clpX}$, nifS, pepX, pyrG, recG, rplB, and uvrA). In order to obtain the sequences from these genes, we employed previously described methods with slight modification [47]. Briefly, nested PCRs using Ex Taq Hot Start version (Takara Bio, Shiga, Japan) were performed without the touchdown step, initially. Then, for the samples that failed to amplify, we repeated the PCR with the touchdown step. Finally, the PCR products were observed with gel electrophoresis and purified using a FastGene Gel/PCR Extraction Kit (Nippon Genetics, Tokyo, Japan), followed by Sanger sequencing.

\subsection{Sequencing and Phylogenetic Analyses}

The sequences were assembled and trimmed using the ATGC software version 6.0.4 (GENETYX, Tokyo, Japan) and compared with the sequences available in public databases using BLASTn. The phylogenetic trees were constructed using MEGA version X [75] with Neighbor-Joining or maximum likelihood models and the Kimura 2-parameter model with pairwise deletion and 1000 bootstrap replications. The phylogenetic relationships of the Borrelia spp. were also analyzed using the concatenated sequences of the eight genes and those of closely related Borrelia spp. downloaded from the PubMLST database (https://pubmlst.org/). The sequences obtained in this study are available in the GenBank database with following accession numbers: flaB (LC572294-LC572312), 16S rDNA (LC572071-LC572081), clpA (LC572082-LC572087), clpX (LC572088-LC572095), nifS (LC572096-LC572101), pepX (LC572102-LC572111), pyrG (LC572112-LC572119), recG (LC572120-LC572128), rplB (LC572129LC572136), and uvrA (LC572137-LC572145).

Supplementary Materials: The following are available online at http://www.mdpi.com/2076-0817/9/10/846/s1, Figure S1: Phylogenetic inference of Borrelia burgdorferi sensu lato included rodent samples, based on individual housekeeping genes. (A) $\operatorname{clpX},(\mathrm{B}) \operatorname{pepX},(\mathrm{C}) \operatorname{pyrG},(\mathrm{D}) \operatorname{rec} G,(\mathrm{E}) \operatorname{rplB},(\mathrm{F}) \mathrm{uvrA}$.

Author Contributions: Conceptualization, investigation, formal analysis, visualization, writing—original draft preparation, A.C.C.L. and Y.Q.; methodology, A.C.C.L., Y.Q., M.A.M.M. and R.N.; validation, Y.Q.; writing-review and editing, A.C.C.L., Y.Q., M.A.M.M., R.N., M.S. and T.T.; resources, A.C.C.L., Y.Q., M.A.M.M., R.N., M.S., M.O., J.M.-A. and T.T.; supervision, Y.Q. and T.T.; project administration, A.C.C.L., Y.Q., M.A.M.M., J.M.-A. and T.T.; funding acquisition, Y.Q., M.O. and T.T. All authors have read and agreed to the published version of the manuscript.

Funding: This research was funded by Japan International Cooperation Agency (JICA) and Ohyama Health Foundation Inc. 
Acknowledgments: The authors would like to thank Nobuyoshi Nakajima of the National Institute for Environmental Studies, Japan, for his technical support. The authors also extend appreciation to Madinah Adrus, Sally Soo KaiCheen, Raja Nur Atiqah, Lisa Lok, Trevor Allen Nyaseng, and Anita anak Muli of the Institute of Biodiversity and Environmental Conservation, Universiti Malaysia Sarawak (UNIMAS), for coordinating and assisting in the field sampling.

Conflicts of Interest: The authors declare no conflict of interest.

\section{References}

1. Margos, G.; Gofton, A.; Wibberg, D.; Dangel, A.; Marosevic, D.; Loh, S.M.; Oskam, C.; Fingerle, V. The genus Borrelia reloaded. PLoS ONE 2018, 13, e0208432. [CrossRef] [PubMed]

2. Margos, G.; Fingerle, V.; Cutler, S.; Gofton, A.; Stevenson, B.; Estrada-Pena, A. Controversies in bacterial taxonomy: The example of the genus Borrelia. Ticks Tick Borne Dis. 2020, 11, 101335. [CrossRef] [PubMed]

3. Hengge, U.R.; Tannapfel, A.; Tyring, S.K.; Erbel, R.; Arendt, G.; Ruzicka, T. Lyme borreliosis. Lancet Infect. Dis. 2003, 3, 489-500. [CrossRef]

4. Piesman, J.; Gern, L. Lyme borreliosis in Europe and North America. Parasitology 2004, 129, S191-S220. [CrossRef] [PubMed]

5. Fesler, M.C.; Shah, J.S.; Middelveen, M.J.; du Cruz, I.; Burrascano, J.J.; Stricker, R.B. Lyme disease: Diversity of Borrelia species in California and Mexico detected using a novel immunoblot assay. Healthcare 2020, 8, 97. [CrossRef] [PubMed]

6. Margos, G.; Lane, R.S.; Fedorova, N.; Koloczek, J.; Piesman, J.; Hojgaard, A.; Sing, A.; Fingerle, V. Borrelia bissettiae sp. nov. and Borrelia californiensis sp. nov. prevail in diverse enzootic transmission cycles. Int. J. Syst. Evol. Microbiol. 2016, 66, 1447-1452. [CrossRef]

7. Margos, G.; Hojgaard, A.; Lane, R.S.; Cornet, M.; Fingerle, V.; Rudenko, N.; Ogden, N.; Aanensen, D.M.; Fish, D.; Piesman, J. Multilocus sequence analysis of Borrelia bissettiae strains from North America reveals a new Borrelia species, Borrelia kurtenbachii. Ticks Tick-Borne Dis. 2010, 1, 151-158. [CrossRef]

8. Pritt, B.S.; Respicio-Kingry, L.B.; Sloan, L.M.; Schriefer, M.E.; Replogle, A.J.; Bjork, J.; Liu, G.; Kingry, L.C.; Mead, P.S.; Neitzel, D.F.; et al. Borrelia mayonii sp. nov., a member of the Borrelia burgdorferi sensu lato complex, detected in patients and ticks in the upper midwestern United States. Int. J. Syst. Evol. Microbiol. 2016, 66, 4878-4880. [CrossRef]

9. Richter, D.; Postic, D.; Sertour, N.; Livey, I.; Matuschka, F.-R.; Baranton, G. Delineation of Borrelia burgdorferi sensu lato species by multilocus sequence analysis and confirmation of the delineation of Borrelia spielmanii sp. nov. Int. J. Syst. Evol. Microbiol. 2006, 56, 873-881. [CrossRef]

10. Strnad, M.; Honig, V.; Ruzek, D.; Grubhoffer, L.; Rego, R.O.M. Europe-wide meta-analysis of Borrelia burgdorferi sensu lato prevalence in questing Ixodes ricinus ticks. Appl. Environ. Microbiol. 2017, 83, e00609-e00617. [CrossRef]

11. Kawabata, M.; Baba, S.; Iguchi, K.; Yamaguti, N.; Russell, H. Lyme disease in Japan and its possible incriminated tick vector, Ixodes persulcatus. J. Infect. Dis. 1987, 156, 854. [CrossRef] [PubMed]

12. Masuzawa, T. Terrestrial distribution of the Lyme Borreliosis agent Borrelia burgdorferi sensu lato in east Asia. Jpn. J. Infect. Dis. 2004, 57, 229-235. [PubMed]

13. Barbour, A.G. Relapsing fever. In Tick-Borne Diseases of Human; Jesse, L., Goodman, D.T.D., Sonenshine, D.E., Eds.; ASM Press: Washington, DC, USA, 2005; pp. 268-291.

14. Trape, J.F.; Diatta, G.; Arnathau, C.; Bitam, I.; Sarih, M.; Belghyti, D.; Bouattour, A.; Elguero, E.; Vial, L.; Mane, Y.; et al. The epidemiology and geographic distribution of relapsing fever borreliosis in West and North Africa, with a review of the Ornithodoros erraticus complex (Acari: Ixodida). PLoS ONE 2013, 8, e78473. [CrossRef] [PubMed]

15. Smith, R.D.; Brener, J.; Osorno, M.; Ristic, M. Pathobiology of Borrelia theileri in the tropical cattle tick, Boophilus microplus. J. Invertebr. Pathol. 1978, 32, 182-190. [CrossRef]

16. Fukunaga, M.; Takahashi, Y.; Tsuruta, Y.; Matsushita, O.; Ralph, D.; McClelland, M.; Nakao, M. Genetic and phenotypic analysis of Borrelia miyamotoi sp. nov., isolated from the ixodid tick Ixodes persulcatus, the vector for Lyme disease in Japan. Int. J. Syst. Bacteriol. 1995, 45, 804-810. [CrossRef] 
17. Armstrong, P.M.; Rich, S.M.; Smith, R.D.; Hartl, D.L.; Spielman, A.; Telford, S.R. A new Borrelia infecting Lone Star ticks. Lancet 1996, 347, 67-68. [CrossRef]

18. Platonov, A.E.; Karan, L.S.; Kolyasnikova, N.M.; Makhneva, N.A.; Toporkova, M.G.; Maleev, V.V.; Fish, D.; Krause, P.J. Humans infected with relapsing fever spirochete Borrelia miyamotoi, Russia. Emerg. Infect. Dis. 2011, 17, 1816-1823. [CrossRef]

19. Smith, R.D.; Miranpuri, G.S.; Adams, J.H.; Ahrens, E.H. Borrelia theileri: Isolation from ticks (Boophilus microplus) and tick-borne transmission between splenectomized calves. Am. J. Vet. Res. 1985, $46,1396-1398$.

20. Hovius, J.W.R.; de Wever, B.; Sohne, M.; Brouwer, M.C.; Coumou, J.; Wagemakers, A.; Oei, A.; Knol, H.; Narasimhan, S.; Hodiamont, C.J.; et al. A case of meningoencephalitis by the relapsing fever spirochaete Borrelia miyamotoi in Europe. Lancet 2013, 382, 658. [CrossRef]

21. Krause, P.J.; Narasimhan, S.; Wormser, G.P.; Rollend, L.; Fikrig, E.; Lepore, T.; Barbour, A.; Fish, D. Human Borrelia miyamotoi infection in the United States. New Engl. J. Med. 2013, 368, 291-293. [CrossRef]

22. Sato, K.; Takano, A.; Konnai, S.; Nakao, M.; Ito, T.; Koyama, K.; Kaneko, M.; Ohnishi, M.; Kawabata, H. Human infections with Borrelia miyamotoi, Japan. Emerg. Infect. Dis. 2014, 20, 1391-1393. [CrossRef]

23. Jiang, B.G.; Jia, N.; Jiang, J.F.; Zheng, Y.C.; Chu, Y.L.; Jiang, R.R.; Wang, Y.W.; Liu, H.B.; Wei, R.; Zhang, W.H.; et al. Borrelia miyamotoi infections in humans and ticks, Northeastern China. Emerg. Infect. Dis. 2018, 24, 236-241. [CrossRef] [PubMed]

24. Mohammed, K.; Tukur, S.M.; Watanabe, M.; Abd Rani, P.A.M.; Lau, S.F.; Shettima, Y.M.; Watanabe, M. Factors influencing the prevalence and distribution of ticks and tick-borne pathogens among domestic animals in Malaysia. Pertanika J. Sch. Reserve Rev. 2016, 2, 12-22.

25. Bryan, J.E.; Shearman, P.L.; Asner, G.P.; Knapp, D.E.; Aoro, G.; Lokes, B. Extreme differences in forest degradation in Borneo: Comparing practices in Sarawak, Sabah, and Brunei. PLoS ONE 2013, 8, e69679. [CrossRef]

26. Gaveau, D.L.A.; Sloan, S.; Molidena, E.; Yaen, H.; Sheil, D.; Abram, N.K.; Ancrenaz, M.; Nasi, R.; Quinones, M.; Wielaard, N.; et al. Four decades of forest persistence, clearance and logging on Borneo. PLoS ONE 2014, 9, e101654. [CrossRef] [PubMed]

27. Wilcox, B.A.; Duane, J.; Gubler, D.J. Disease ecology and the global emergence of zoonotic pathogens. Environ. Health Prev. Med. 2005, 10, 263-272. [CrossRef]

28. Zohdy, S.; Schwartz, T.S.; Oaks, J.R. The coevolution effect as a driver of spillover. Trends Parasitol. 2019, 35, 399-408. [CrossRef] [PubMed]

29. Khoo, J.J.; Lim, F.S.; Tan, K.K.; Chen, F.S.; Phoon, W.H.; Khor, C.S.; Pike, B.L.; Chang, L.Y.; AbuBakar, S. Detection in Malaysia of a Borrelia sp. from Haemaphysalis hystricis (Ixodida: Ixodidae). J. Med. Entomol. 2017, 54, 1444-1448. [CrossRef] [PubMed]

30. Khoo, J.J.; Ishak, S.N.; Lim, F.S.; Mohd-Taib, F.S.; Khor, C.S.; Loong, S.K.; AbuBakar, S. Detection of a Borrelia sp. from Ixodes granulatus ticks collected from rodents in Malaysia. J. Med. Entomol. 2018, 55, 1642-1647. [CrossRef]

31. Tay, S.T.; Kamalanathan, M.; Rohani, M.Y. Borrelia burgdorferi (strain B. afzelli) antibodies among Malaysian blood donor and patients. Southeast Asian J. Trop. Med. Public Health 2002, 33, 787-793.

32. Khor, C.S.; Hassan, H.; Mohd-Rahim, N.F.; Chandren, J.R.; Nore, S.S.; Johari, J.; Loong, S.K.; Abd-Jamil, J.; Khoo, J.J.; Lee, H.Y.; et al. Seroprevalence of Borrelia burgdorferi among the indigenous people (Orang Asli) of peninsular Malaysia. J. Infect. Dev. Ctries. 2019, 13, 449-454. [CrossRef]

33. Margos, G.; Chu, C.Y.; Takano, A.; Jiang, B.G.; Liu, W.; Kurtenbach, K.; Masuzawa, T.; Fingerle, V.; Cao, W.C.; Kawabata, H. Borrelia yangtzensis sp. nov., a rodent-associated species in Asia, is related to Borrelia valaisiana. Int. J. Syst. Evol. Microbiol. 2015, 65, 3836-3840. [CrossRef]

34. Wang, G.; van Dam, A.P.; Schwartz, I.; Dankert, J. Molecular typing of Borrelia burgdorferi sensu lato: Taxonomic, epidemiological, and clinical implications. Clin. Microbiol. Rev. 1999, 12, 633-653. [CrossRef]

35. Kawabata, H.; Takano, A.; Kadosaka, T.; Fujita, H.; Nitta, Y.; Gokuden, M.; Honda, T.; Tomida, J.; Kawamura, Y.; Masuzawa, T.; et al. Multilocus sequence typing and DNA similarity analysis implicates that a Borrelia valaisiana-related sp. isolated in Japan is distinguishable from European, B. valaisiana. J. Vet. Med. Sci. 2013, 75, 1201-1207. [CrossRef] [PubMed] 
36. Masuzawa, T.; Pan, M.J.; Kadosaka, T.; Kudeken, M.; Takada, N.; Yano, Y.; Imai, Y.; Yanagihara, Y. Characterization and identification of Borrelia isolates as Borrelia valaisiana in Taiwan and Kinmen Islands. Microbiol. Immunol. 2000, 44, 1003-1009. [CrossRef]

37. Masuzawa, T.; Hashimoto, N.; Kudeken, M.; Kadosaka, T.; Nakamura, M.; Kawabata, H.; Koizumi, N.; Imai, Y. New genomospecies related to Borrelia valaisiana, isolated from mammals in Okinawa archipelago, Japan. J. Med. Microbiol. 2004, 53, 421-426. [CrossRef]

38. Masuzawa, T.; Fukui, T.; Miyake, M.; Oh, H.B.; Cho, M.K.; Chang, W.H.; Imai, Y.; Yanagihara, H. Determination of members of a Borrelia afzelii-related group isolated from Ixodes nipponensis in Korea as Borrelia valaisiana. Int. J. Syst. Evol. Microbiol. 1999, 49, 1409-1415. [CrossRef]

39. Chu, C.Y.; Liu, W.; Jiang, B.G.; Wang, D.M.; Jiang, W.J.; Zhao, Q.M.; Zhang, P.H.; Wang, Z.X.; Tang, G.P.; Yang, H.; et al. Novel genospecies of Borrelia burgdorferi sensu lato from rodents and ticks in southwestern China. J. Clin. Microbiol. 2008, 46, 3130-3133. [CrossRef]

40. Takhampunya, R.; Korkusol, A.; Pongpichit, C.; Yodin, K.; Rungrojn, A.; Chanarat, N.; Promsathaporn, S.; Monkanna, T.; Thaloengsok, S.; Tippayachai, B.; et al. Metagenomic approach to characterizing disease epidemiology in a disease-endemic environment in northern Thailand. Front Microbiol. 2019, 10, 319. [CrossRef]

41. Kuo, C.; Lin, Y.; Yao, C.; Shih, H.; Chung, L.; Liao, H.; Hsu, Y.; Wang, H. Tick-borne pathogens in ticks collected from birds in Taiwan. Parasit. Vectors 2017, 10, 587. [CrossRef]

42. Miyamoto, K.; Sato, Y.; Okada, K.; Fukunaga, M.; Sato, F. Competence of a migratory bird, red-bellied thrush (Turdus chrysolaus), as an avian reservoir for the Lyme disease spirochetes in Japan. Acta Tropica 1997, 65, 43-51. [CrossRef]

43. Kang, J.G.; Kim, H.C.; Choi, C.Y.; Nam, H.Y.; Chae, H.Y.; Chong, S.T.; Klein, T.A.; Ko, S.; Chae, J.S. Molecular detection of Anaplasma, Bartonella, and Borrelia species in ticks collected from migratory birds from Hong-do Island, Republic of Korea. Vector Borne Zoonotic Dis. 2013, 13, 215-225. [CrossRef] [PubMed]

44. Movila, A.; Alekseev, A.N.; Dubinina, H.V.; Toderas, I. Detection of tick-borne pathogens in ticks from migratory birds in the Baltic region of Russia. Med Vet. Entomol. 2013, 27, 113-117. [CrossRef] [PubMed]

45. Scott, J.D.; Clark, K.L.; Foley, J.E.; Bierman, B.C.; Durden, L.A. Far-reaching dispersal of Borrelia burgdorferi sensu lato-infected Blacklegged ticks by migratory songbirds in Canada. Healthcare 2018, 6, 89. [CrossRef]

46. Scott, J.D.; Clark, K.L.; Foley, J.E.; Anderson, J.F.; Bierman, B.C.; Durden, L.A. Extensive distribution of the Lyme disease bacterium, Borrelia burgdorferi sensu lato, in multiple tick species parasitizing avian and mammalian hosts across Canada. Healthcare 2018, 6, 131. [CrossRef]

47. Margos, G.; Gatewood, A.G.; Aanensen, D.M.; Hanincova, K.; Terekhova, D.; Vollmer, S.A.; Cornet, M.; Piesman, J.; Donaghy, M.; Bormane, A.; et al. MLST of housekeeping genes captures geographic population structure and suggests a European origin of Borrelia burgdorferi. Proc. Natl. Acad. Sci. USA 2008, 105, 8730-8735. [CrossRef]

48. Mtierova, Z.; Derdakova, M.; Chvostac, M.; Didyk, Y.M.; Mangova, B.; Taragelova, V.R.; Selyemova, D.; Sujanova, A.; Vaclav, R. Local population structure and seasonal variability of Borrelia garinii genotypes in Ixodes ricinus ticks, Slovakia. Int. J. Environ. Res. Public Health 2020, 17, 3607. [CrossRef]

49. Norte, A.C.; Margos, G.; Becker, N.S.; Albino Ramos, J.; Núncio, M.S.; Fingerle, V.; Araújo, P.M.; Adamík, P.; Alivizatos, H.; Barba, E.; et al. Host dispersal shapes the population structure of a tick-borne bacterial pathogen. Mol. Ecol. 2020, 29, 485-501. [CrossRef]

50. Margos, G.; Sing, A.; Fingerle, V. Published data do not support the notion that Borrelia valaisiana is human pathogenic. Infection 2017, 45, 567-569. [CrossRef]

51. Saito, K.; Ito, T.; Asashima, N.; Ohno, M.; Nagai, R.; Fujita, H.; Koizumi, N.; Takano, A.; Watanabe, H.; Kawabata, H. Case report: Borrelia valaisiana infection in a Japanese man associated with traveling to foreign countries. Am. J. Trop. Med. Hyg. 2007, 77, 1124-1127. [CrossRef]

52. Ni, X.B.; Jia, N.; Jiang, B.G.; Sun, T.; Zheng, Y.C.; Huo, Q.B.; Liu, K.; Ma, L.; Zhao, Q.M.; Yang, H.; et al. Lyme borreliosis caused by diverse genospecies of Borrelia burgdorferi sensu lato in northeastern China. Clin. Microbiol. Infect. 2014, 20, 808-814. [CrossRef] 
53. Yun, S.M.; Lee, W.G.; Ryou, J.; Yang, S.C.; Park, S.W.; Roh, J.Y.; Lee, Y.J.; Park, C.; Han, M.G. Severe fever with thrombocytopenia syndrome virus in ticks collected from humans, South Korea, 2013. Emerg. Infect. Dis. 2014, 20, 1358-1361. [CrossRef]

54. Tanskul, P.; Stark, H.E.; Inlao, I. A checklist of ticks of Thailand (Acari: Metastigmata: Ixodoidea). J. Med. Entomol. 1983, 20, 330-341. [CrossRef] [PubMed]

55. Krause, P.J.; Fish, D.; Narasimhan, S.; Barbour, A.G. Borrelia miyamotoi infection in nature and in humans. Clin. Microbiol. Infect. 2015, 21, 631-639. [CrossRef] [PubMed]

56. Pukhovskaya, N.M.; Morozova, O.V.; Vysochina, N.P.; Belozerova, N.B.; Ivanov, L.I. Prevalence of Borrelia burgdorferi sensu lato and Borrelia miyamotoi in ixodid ticks in the far east of Russia. Int. J. Parasitol. Parasites Wildl. 2019, 8, 192-202. [CrossRef]

57. Dibernardo, A.; Cote, T.; Ogden, N.H.; Lindsay, L.R. The prevalence of Borrelia miyamotoi infection, and co-infections with other Borrelia spp. In Ixodes scapularis ticks collected in Canada. Parasit. Vectors 2014, 7, 183. [CrossRef]

58. Taylor, K.R.; Takano, A.; Konnai, S.; Shimozuru, M.; Kawabata, H.; Tsubota, T. Borrelia miyamotoi infections among wild rodents show age and month independence and correlation with Ixodes persulcatus larval attachment in Hokkaido, Japan. Vector Borne Zoonotic Dis. 2013, 13, 92-97. [CrossRef]

59. Lommano, E.; Dvorak, C.; Vallotton, L.; Jenni, L.; Gern, L. Tick-borne pathogens in ticks collected from breeding and migratory birds in Switzerland. Ticks Tick Borne Dis. 2014, 5, 871-882. [CrossRef] [PubMed]

60. Wagemakers, A.; Staarink, P.J.; Sprong, H.; Hovius, J.W.R. Borrelia miyamotoi: A wide spread tick-borne relapsing fever spirochete. Trends Parasitol. 2015, 31, 260-269. [CrossRef]

61. Barbour, A.G.; Bunikis, J.; Travinsky, B.; Hoen, A.G.; Diuk-Wasser, M.A.; Fish, D.; Tsao, J.I. Niche partitioning of Borrelia burgdorferi and Borrelia miyamotoi in the same tick vector and mammalian reservoir species. Am. J. Trop. Med. Hyg. 2009, 81, 1120-1131. [CrossRef]

62. Zawada, S.G.; von Fricken, M.E.; Weppelmann, T.A.; Sikaroodi, M.; Gillevet, P.M. Optimization of tissue sampling for Borrelia burgdorferi in white-footed mice (Peromyscus leucopus). PLoS ONE 2020, 15, e0226798. [CrossRef] [PubMed]

63. Gibb, R.; Redding, D.W.; Chin, K.Q.; Donnelly, C.A.; Blackburn, T.M.; Newbold, T.; Jones, K.E. Zoonotic host diversity increases in human-dominated ecosystems. Nature 2020. [CrossRef] [PubMed]

64. LoGiudice, K.; Ostfeld, R.S.; Schmidt, K.A.; Keesing, F. The ecology of infectious disease: Effects of host diversity and community composition on Lyme disease risk. Proc. Natl. Acad. Sci. USA 2003, 100, 567-571. [CrossRef] [PubMed]

65. Robins, J.H.; Hingston, M.; Matisoo-Smith, E.; Ross, H.A. Identifying Rattus species using mitochondrial DNA. Mol. Ecol. Notes 2007, 7, 717-729. [CrossRef]

66. Kohls, G.M. Tick (Ixodoidae) of Borneo and Malaya. Malays. Parasites 1957, 28, 65-94.

67. Che Lah, E.F.; Yaakop, S.; Ahmad, M.; George, E.; Md Nor, S. Precise identification of different stages of a tick, Ixodes granulatus Supino, 1897 (Acari: Ixodidae). Asian Pac. J. Trop. Biomed. 2016, 6, 597-604. [CrossRef]

68. Ushijima, Y.; Oliver, J.H.; Keirans, J.E.; Tsurumi, M.; Kawabata, H.; Watanabe, H.; Fukunaga, M. Mitochondrial sequence variation in Carlos capensis (Neumann), a parasite of seabirds, collected on Torishima Island in Japan. J. Parasitol. 2003, 89, 196-198. [CrossRef]

69. Mtambo, J.; Van Bortel, W.; Madder, M.; Roelants, P.; Backeljau, T. Comparison of preservation methods of Rhipicephalus appendiculatus (Acari: Ixodidae) for reliable DNA amplification by PCR. Exp. Appl. Acarol. 2006, 38, 189-199. [CrossRef] [PubMed]

70. Ratnasingham, S.; Hebert, P.D. Bold: The barcode of life data system (http://www.barcodinglife.org). Mol. Ecol. Notes 2007, 7, 355-364. [CrossRef]

71. Takano, A.; Goka, K.; Une, Y.; Shimada, Y.; Fujita, H.; Shiino, T.; Watanabe, H.; Kawabata, H. Isolation and characterization of a novel Borrelia group of tick-borne borreliae from imported reptiles and their associated ticks. Environ. Microbiol. 2010, 12, 134-146. [CrossRef] [PubMed]

72. Weisburg, W.G.; Barns, S.M.; Pelletier, D.A.; Lane, D.J. 16 S ribosomal DNA amplification for phylogenetic study. J. Bacteriol. 1991, 173, 697-703. [CrossRef] [PubMed]

73. Roux, V.; Raoult, D. Body lice as tools for diagnosis and surveillance of reemerging diseases. J. Clin. Microbiol. 1999, 37, 596-599. [CrossRef] [PubMed] 
74. Qiu, Y.; Nakao, R.; Hang'ombe, B.M.; Sato, K.; Kajihara, M.; Kanchela, S.; Changula, K.; Eto, Y.; Ndebe, J.; Sasaki, M.; et al. Human borreliosis caused by a New World Relapsing Fever Borrelia-like organism in the Old World. Clin. Infect. Dis. 2019, 69, 107-112. [CrossRef] [PubMed]

75. Kumar, S.; Stecher, G.; Li, M.; Knyaz, C.; Tamura, K. MEGA X: Molecular evolutionary genetics analysis across computing platforms. Mol. Biol. Evol. 2018, 35, 1547-1549. [CrossRef]

Publisher's Note: MDPI stays neutral with regard to jurisdictional claims in published maps and institutional affiliations.

(C) 2020 by the authors. Licensee MDPI, Basel, Switzerland. This article is an open access article distributed under the terms and conditions of the Creative Commons Attribution (CC BY) license (http://creativecommons.org/licenses/by/4.0/). 